\title{
PREVALENCE AND CHARACTERISTICS OF TEENAGE PREGNANCY AT DR. HASAN SADIKIN HOSPITAL, BANDUNG, WEST JAVA
}

\author{
Zulvayanti, Windi Nurdiawan, Dini Hidayat, Hadi Susiarno, Dini \\ Pusianawati, and Fadhilah Zulfa
}

\author{
Department Obstetric and Genecology, Dr. Hasan Sadikin Hospital, \\ Universitas Padjadjaran
}

\begin{abstract}
Background: Teenage pregnancy has been viewed with increasing concern in recent years. Health concerns have focused on the medical risks to the young mother and her infant. Teenage women have been reported at increased risk of pregnancy complications, postnatal depression and, if married, of early marital breakdown. This study aimed to determine the prevalence and characteristics of teenage pregnancy at Dr. Hasan Sadikin Hospital, Bandung, and West Java.

Subjects and Method: This was a descriptive study carried out at Dr. Hasan Sadikin Hospital, Bandung. A sample of 471 pregnant teenagers aged $<20$ years old was selected for this study. The dependent variable was characteristics of the teenage pregnancy. The data were collected by medical records and analyzed descriptively.

Results: The prevalence of teenage pregnancy at Dr. RSUP Hasan Sadikin was $4.57 \%$. $1.48 \%$ were $<15$ years old, $38.22 \%$ aged between 15 to 17 years, and $60.30 \%$ aged 18 and 19 years. 56.90\% without complication. 21.66\% suffered preterm labor complication. 8.92\% suffered contraction disorder. 3.61\% suffered location abnormality. $2.97 \%$ were old stage II. $2.34 \%$ were fetal distress. $1.91 \%$ had post-delivery bleeding. $0.85 \%$ had cord prolapse. $0.42 \%$ had prolonged post-delivery bleeding. $0.21 \%$ had vacuum failure and fetal abnormality.

Conclusion: The prevalence of teenage pregnancy at Dr. RSUP Hasan Sadikin is $4.57 \%$. Nearly half of teenage pregnancy have complications before labor, during labor, and postpartum.
\end{abstract}

Keywords: teenage pregnancy, characteristics, age, complication

\section{Correspondence:}

Zulvayanti. Department Obstetric and Genecology, Dr. Hasan Sadikin Hospital, Universitas Padjadjaran, Bandung, Jl. Pasteur No. 38, Bandung 40161, Indonesia. Email: zyanti228227@gmail.com. Mobile: (+6222)2032530.

The 5th International Conference on Public Health Best Western Premier Hotel, Solo, Indonesia, February 13-14, 2019 | 323

https://doi.org/10.26911/theicph.2019.03.52 